\title{
KONSEP EKONOMI MASA KHULAFAUR RASYIDIN
}

\author{
Oleh : Nela Novyanti (90100118098)
}

Setelah Rasulullah kemudian wafat, khulafaur rasyidin menggantikan beliau dalam melanjutan tonggak Islam sekaligus ekonomi Islam yang tengah kacau selepas rasulullah wafat. (Rahma dan idris 2019). Berikut konsep perjalanan khalifah dalam masa pemerintahannya:

A. Masa Abu Bakar As-Shiddiq ra.

Masa pemerintahan Abu Bakar berjalan kurag lebih 1 sampai 2 tahun dimana Islam Berembang ke Romawi dan Persia. Selama masa pemerintahannya beliau menghdapi banyak permesalahan mulai dari munculnya nabi palsu, banyaknya kemudaratan serta pembangkan zakat setelah rasulullah wafat yang akhirnya menimbulkan perang ridha. (Mussyaddad 2013).

Meskipun begitu beliau sangat terkenal dengan keakuratan dalam perhitungan zakat serta sangat adil dan menjunjung kesamarataan dalam masyarakat kala itu.

B. Umar Bin Khattab ra.

Sebagai penggnti Abu Bakar masa pemerimtaha Umar bisa dibilang cukup lama yakni 10 tahun. Dengan waktu yang terbilang tidak singkat itu beliau berhasil memperluas wilayah hingga Jazirah Arab, Palestina, Mesir, Syiriah dan Persia. Kemudian menatanya menjadi 8 provinsi, yakini Mekkah, Madinah, Syirah, Jazirah, Basrah, Kufah, Palestina dan Mesir.

Salah satu pratik ekonomi Islam pada masa Umar ini ialah adanya Baitul Mal dan pajak pengelolaan tanah kharaj yang disita dari Negara yang 
ditaklukkan. Selain itu umar dalam megelolah zakat ia memperluas objek zakat misalnya zakat perdagangan, peternaan dan pertanian. (Akbar dan Iskandar 2019).

C. Ustman Bin Affan

Setelah Umar wafat beliau digantikan oleh Ustman yang memerintah selama 12 tahun. Ustman kemudian melakukan perluasan wilayah secara masif, melakukan pembangunan jalan dan membentuk polisi pengawas perdagangan. Adapun kebijakan Ustman paa saat itu ialah tida mengambil upah atas pekerjaannya yang kemudian mengakibatkan konflik.

Masa pemerintahan ustman ini pula terdapat berbagai gangguan dan pendapat kontroversional mengenai kebijakan yang ia keluarkan.

D. Ali Bin Abi Thalib

Ali Bin Abi Thalib adalah khulafaur rasidin ke empat sekaligus terakhir yang menggantikan Utsman yang meninggal terbunuh. Khalifa Ali adalah sosok yag sederhana ia dengan suka rela menarik dirinya dari daftar penerima Baitul Mal serta memberikan sumbangan dari harta miliknya sebesar 5000 dirham setiap tahunnya.

Adapun kebijakan saat beliau memerintah ialah menetapkan pajak pemilik hutan sebesar 4000 dirham dan mengizinkan pemungutan zakat terhadap sayuran untuk bumbu masakan. Keeistimewaannya ialah mampu mengatur masalah administrasi umum secara rapi. (Kharidatul, 2015). 


\section{DAFTAR PUSTAKA}

Aqbar, Khaerul dan Azwar Iskandar. (2019) Kontekstualisasi Zaat dalam Mengenntaskan Kemiskinan :Studi Kebijakan Zakat Umar Bin Khattab Dan Perzakatan di Indoenesia. Jurnal Laa Maysir. Vol 5. No 1.

Mudhiaah, Kharidatul. (2015). Sejarah Pemikiran Ekonomi Islam Masa Klasik. Vol 8, No 2.

Musyaddad, Ahmad. 2013. Kebijakan Fiskal di Masa Pemerintahan Abu Bakar As-Shiddiq. Jurnal Ekonomi Islam. Vol 4. No 2.

Rahmah, Nur dan Munadi Idris. 2019. Masa Keemasan Ekonomi Islam (Perspektif Syariah). Jurnal Ekonomi Binis Syariah. Vol 2. No.1. 